\title{
Nutrient utilization of acacia, haloxylon, and atriplex spe- cies by Najdi sheep
}

ASHOK N. BHATTACHARYA

\section{Abstract}

Two digestibility and nitrogen balance studies were conducted to evaluate nutrient utilization of 3 commonly browsed range plants by the desert sheep in Northern Saudi Arabia. In experiment 1 , 15 Najdi wether lambs $(40 \mathrm{~kg}$ ) divided in 3 lots of 5 were randomly allotted to 3 diets of $200 \mathrm{~g}$ ground barley (Fordeum vulgare L.) grain and $800 \mathrm{~g}$ either alfalfa hay (Medicago sativa L.), dried Acacia cynophylla Lind., or Haloxylon persicum Bge. clippings. In experiment 2, 8 Najdi wethers were randomly alloted to treatments of $2 \mathrm{~kg}$ green alfalifa or $2 \mathrm{~kg}$ green Atriplex haltmus L. clippings per day. Salt content of the soil and salt bush, Atrplex sp., were also determined. The organic matter (OM), crude protein (CP), and crude fiber (CF) on dry matter basis (DMB) were, reapectively, $90,15,31 \%$ for alfalia; $90,13,30 \%$ for acacia forage; and $87,10,37 \%$ for haloxylon shrub. In experiment 1 , the $\mathbf{O M}$ digestibility was 66, 56, 53\%; CP digestibillty was 73, 68, and 55\%; and CF digestibility was 44,33 , and $16 \%$, respectively, for alfalia, haloxylon, and acacia diets. The dally nitrogen balance was $+4 \mathrm{~g}$ for both alfalfa and acacia groups. The haloxylon group had a negative nitrogen balance $(-1.9 \%)$, showing no apparent retention of absorbed nitrogen. In experiment 2, the atriplex clippings contained $73 \% \mathrm{OM}, 18 \% \mathrm{CP}$, and $24 \% \mathrm{CF}$ on DMB, the respective digestibility values being 61,79 , and $39 \%$. Even though the digestibility of as well as percent retention of absorbed nitrogen in atriplex group were markedly higher than those in alfalfa group, the digestibility of CF was lower $(P<.01)$ in the former $(39 \%)$ as compared to that in latter group (54\%). The sodium, potassium, and chloride concentration of soils of high and low salinity had no influence on their contents in atriplex forage, with average values being $10,2.5$, and $16.5 \%$ respectively.

Key Words: Medicago sativa, A cacia cynophylla, Haloxylon persicum, Atriplex haltmus, shrubs, desert sheep, Northern Saudi Arabia, salinity, digestibility, nitrogen retention

Rangelands cover more than $90 \%$ of the area of northern Saudi Arabia and are of major importance for the livestock industry in the kingdom. The land units consist principally of sand dunes, wadis, gravel plains, and stone hills. Best soils are found in the large wadis and around oases where silt and clays have been deposited as a result of occasional floods. Usually vegetation is restricted to drainages and depressions, leaving the rest of the land bare with a few annuals. Dwarf shrubs and annual forbs form the best part of vegetation. Bedouins raise most of the livestock in the desert ranges. Native fat-tailed sheep which are dominant in the area make chief use of the rangeland resources along with goats and camels.

Systematic studies for nutritional evaluation of desert range shrubs of Saudi Arabia by in vivo or in vitro techniques are lacking. Feed values calculated from standard chemical analysis using prediction equations derived from conventional feeds are not applicable for desert shrubs. Further, native sheep adapted to dry, hot and saline desert conditions might have different nutrient

Author is an FAO animal production specialist, AGAP, FAO, Rome, Italy. Contribution from Range and Animal Development Research Center, Al-jouf, Ministry of Agriculture and Water, Saudia Arabia.

Manuscript accepted 9 June 1988. utilization efficiency than other breeds in different environments. There is a great need to determine the nutrient availability of forage shrubs to assess their deficiencies and contribution towards the requirements of the range-based livestock. The objective of this study was to evaluate nutrient utilization of 3 commonly grazed browse species of the range by the native sheep of northern Saudi Arabia.

\section{Materials and Methods}

\section{Experiment 1}

A digestion and nitrogen balance trial was conducted with 15 Najdi wether lambs with an average initial body weight of $40 \mathrm{~kg}$. The treatment design consisted of 3 groups of 5 wethers each with similar average body weights. Three diets of $200 \mathrm{~g}$ ground barley grain (Hordeum vulgare L.) and $800 \mathrm{~g}$ of either ground alfalfa (Medicago sativa L.) hay, sun-cured Acacia cynophylla Lind. foliage, or dried clippings of Haloxylon persicum Bge. were randomly allotted to 3 groups of sheep. The ingredients and chemical composition of the experimental diets are in Table 1. The alfalfa forage grown in Tabarjal, Al-jouf was harvested at a mid-bloom stage and was sun-cured. The foliages of Acacia sp. consisting of green leaves and tender twigs in a vegetative stage were harvested in early autumn and were sun dried. The clippings of Haloxylon sp. were collected from sand dune areas of the Wadi Sirhan range of Al-jouf province in northern Saudi Arabia and were sun-cured. The area is arid with a very erratic annual rainfall of $30-70 \mathrm{~mm}$, the range of high temperature being $40-45^{\circ} \mathrm{C}$ in summers and $2-4^{\circ} \mathrm{C}$ in winters. All dry forages were coarsely ground in a hammer mill with a screen of $.64 \mathrm{~m}$ mesh size. Diet ingredients were mixed by hand just before feeding twice daily. Iodized salt was fed with the diet at the rate $10 \mathrm{~g}$ per head per day. Daily samples of feed were composited for future analysis. Water was available at all times.

After a 3-week adjustment period in the digestion and metabolism stalls, the trial consisted of a 10-day preliminary period followed by a 7-day total collection of feces and urine. The daily feces were dried for 24 hours at $55^{\circ} \mathrm{C}$ and composited for later analysis. Urine was collected in plastic jars containing $20 \mathrm{ml}$ of dil. sulfuric acid (1:1 by weight) and $500 \mathrm{ml}$ of water. Each 24-hour collection was diluted to a definite volume with water and a $2 \%$ sample by volume was taken; the daily samples were composited in tightly covered jars under refrigeration. Urine was analysed for nitrogen and feed and feces for proximate components according to A.O.A.C. (1980) methods. Calcium was determined by using an atomic absorption spectrophotometer while phosphorus determination was according to Fiske and Subbarow method (1925). All digestible energy (DE) and metabolizable energy (ME) values of the forages were calculated from their digestible organic matter contents (DOM) using the following equation (NRC 1981): $1 \mathrm{~kg}$ $D O M=4.62 \mathrm{Mcal} D E=3.77 \mathrm{Mcal} \mathrm{ME}$. The DOM of the forages were calculated by difference from the values of the respective diets (Lloyd et al. 1978). The standard errors of data were calculated according to Steel and Torrie (1980). Relevant data were subjected to analysis of variance and the difference between treatment means 
Table 1. Ingredient and chemical compoattion of dicts (Experiments 1 and 2).

\begin{tabular}{|c|c|c|c|c|c|}
\hline \multirow{2}{*}{$\begin{array}{l}\text { Experiment no. } \\
\text { Ration no. }\end{array}$} & \multicolumn{3}{|c|}{ I } & \multicolumn{2}{|c|}{ II } \\
\hline & 1 & 2 & 3 & 1 & 2 \\
\hline \multicolumn{6}{|l|}{ Ingredients, gm } \\
\hline Alfalfa hay & $\begin{array}{l}200 \\
800\end{array}$ & 200 & 200 & & \\
\hline Dry acacia foliage & - & 800 & - & & \\
\hline Dry haloxylon shrub & - & - & 800 & & \\
\hline $\begin{array}{l}\text { Green alfalfa } \\
\text { Green atriplex clippings }\end{array}$ & & & & 2000 & 2000 \\
\hline \multicolumn{6}{|l|}{ Chemical composition } \\
\hline Dry matter, \% & 91 & 91 & 91 & 20 & 28 \\
\hline \multicolumn{6}{|c|}{ Percent composition of dry matter } \\
\hline Organic matter & 92 & 91 & 89 & 91 & 73 \\
\hline Crude protein & 14 & 13 & 10 & 22 & 18 \\
\hline Ether extract & 1.4 & 1.3 & 1.4 & 5.6 & 7.6 \\
\hline Crude fiber & 26 & 31 & 31 & 32 & 24 \\
\hline NFE & 50 & 47 & 47 & 32 & 23 \\
\hline Calcium & 1.1 & 2.0 & 0.55 & 2.0 & 0.85 \\
\hline Phosphorus & 0.25 & 0.23 & .16 & 0.21 & 0.17 \\
\hline
\end{tabular}

Table 2. Chemical composition of alfalif hay, acacia foliage and atriplex elippinge (Experiment 1).

\begin{tabular}{lccc}
\hline \hline & Alfalfa & Acacia & Haloxylon \\
\hline Dry matter, \% & 91.3 & 91.6 & 92 \\
$\begin{array}{l}\text { Percent composition of } \\
\text { dry matter }\end{array}$ & & & \\
$\quad$ Organic matter & 90.4 & 89.5 & 87.3 \\
Crude protein & 15.1 & 13.3 & 9.9 \\
Ether extract & 1.34 & 1.20 & 1.30 \\
Crude fiber & 31.0 & 29.6 & 37.4 \\
NFE & 50.5 & 46.0 & 38.7 \\
Calcium & 1.35 & 2.5 & 0.66 \\
Phosphorus & 0.25 & 0.22 & 0.14 \\
\hline
\end{tabular}

were tested by multiple range test (Duncan 1955).

\section{Experiment II.}

A digestion and metabolism trial was conducted with 8 Najdi yearling wethers divided into 2 groups 4 each with similar body weights; 2 diets of either 2 kg green alfalfa or green atriplex clippings (Table 1) were randomly allotted to the 2 groups of sheep.

A perennial salt bush, Atriplex halimus prevalent in the drainage basin area and around Wadi Sirhan range of northern Saudi Arabia was collected every other day during spring (May), when regrowth was abundant. The clippings collected from atriplex plants represented parts consisting of leaves and tender twigs that are mostly annual regrowth and are usually browsed by grazing sheep. Samples of soils at depths of 0,25 , and $50 \mathrm{~cm}$ from the area with visually apparent surface salt deposits as well as of atriplex plants grown on it were collected at random and compared with

Table 3. Apparent digestion coeficients of nutrients in diets (Experiments 1 and 2).

\begin{tabular}{|c|c|c|c|c|c|c|c|}
\hline \multirow{2}{*}{$\begin{array}{l}\text { Experiment no. } \\
\text { Diet no. } \\
\text { Kind of roughage }\end{array}$} & \multicolumn{3}{|c|}{ I } & \multirow[t]{2}{*}{ S.E. } & \multicolumn{2}{|c|}{ II } & \multirow[t]{2}{*}{ S.E. } \\
\hline & $\stackrel{1}{\text { Alfalfa }}$ & $\begin{array}{c}2 \\
\text { Acacia }\end{array}$ & $\stackrel{3}{\text { Haloxylon }}$ & & $\begin{array}{c}1 \\
\text { Alfalfa }\end{array}$ & $\begin{array}{c}2 \\
\text { Atriplex }\end{array}$ & \\
\hline \multicolumn{8}{|c|}{ Apparent digestibility (\%) } \\
\hline $\begin{array}{l}\text { Dry matter } \\
\text { Organic matter } \\
\text { Crude protein } \\
\text { Crude fiber }\end{array}$ & $\begin{array}{l}64^{2} \\
65^{2} \\
73^{2} \\
44^{2}\end{array}$ & $\begin{array}{l}52^{\mathrm{b}} \\
53^{\mathrm{b}} \\
55^{\mathrm{c}} \\
16^{\mathrm{c}}\end{array}$ & $\begin{array}{l}54^{\mathrm{b}} \\
55^{\mathrm{b}} \\
68^{\mathrm{b}} \\
33^{\mathrm{b}}\end{array}$ & $\begin{array}{l} \pm 0.75 \\
\pm 0.75 \\
\pm 1.64 \\
\pm 1.19\end{array}$ & $\begin{array}{l}60^{b} \\
65^{a} \\
71^{b} \\
54^{a}\end{array}$ & $\begin{array}{l}65^{a} \\
61^{b} \\
79^{a} \\
39^{b}\end{array}$ & $\begin{array}{l} \pm 1.00 \\
\pm 1.25 \\
\pm 0.50 \\
\pm 1.50\end{array}$ \\
\hline
\end{tabular}

${ }^{a, b, e}$ Means on the same line of each experiment with different superscripts are significantly different $(\mathcal{P}<.05)$

Table 4. Nitrogen utilization of diets (Experiment 1 and 2).1

\begin{tabular}{|c|c|c|c|c|c|}
\hline \multirow{2}{*}{$\begin{array}{l}\text { Experiment no. } \\
\text { Diet no. } \\
\text { King of roughage }\end{array}$} & \multicolumn{3}{|c|}{1} & \multicolumn{2}{|c|}{ II } \\
\hline & $\begin{array}{c}1 \\
\text { Alfalfa }\end{array}$ & $\begin{array}{c}2 \\
\text { Acacia }\end{array}$ & $\begin{array}{c}3 \\
\text { Haloxylon }\end{array}$ & $\begin{array}{c}1 \\
\text { Alfalfa }\end{array}$ & $\begin{array}{c}2 \\
\text { Atriplex }\end{array}$ \\
\hline Nitrogen consumed, $g / d$ & 20.5 & 18.2 & 13.4 & 14.0 & 15.9 \\
\hline $\begin{array}{l}\text { Nitrogen excreted, g/d } \\
\text { Fecal } \\
\text { Urinary }\end{array}$ & $\begin{array}{r}5.6 \\
10.5\end{array}$ & $\begin{array}{l}8.1 \\
6.2\end{array}$ & $\begin{array}{r}4.3 \\
10.9\end{array}$ & $\begin{array}{l}4.0 \\
7.1\end{array}$ & $\begin{array}{l}3.3 \\
8.0\end{array}$ \\
\hline $\begin{array}{l}\text { Nitrogen retention, } \mathrm{g} / \mathrm{d} \\
\text { Percent of intake } \\
\text { Percent of absorbed }\end{array}$ & $\begin{array}{r}4.4^{a} \\
21.3^{a} \\
29.3^{a}\end{array}$ & $\begin{array}{r}3.9^{b} \\
21.5^{a} \\
38.8^{b}\end{array}$ & $\begin{array}{c}-1.8^{\mathrm{c}} \\
- \\
-\end{array}$ & $\begin{array}{r}2.9^{a} \\
20.7^{a} \\
29.0^{2}\end{array}$ & $\begin{array}{r}4.6^{b} \\
28.8^{b} \\
36.0^{b}\end{array}$ \\
\hline
\end{tabular}

${ }_{a, b, c}$ Means on the same line of each experiment with different superseripts are significantly different $(\mathbb{R}<.05)$. 
salinity of soils and the plants from areas without any visible surface deposits of salt.

The green alfalfa harvested simultaneously as a control forage was at the late vegetative stage of growth and was grown under irrigation at the experimental farm at Tabarjal along the range tract. Both the green alfalfa and green atriplex were cut in small pieces (3-5 cm) and fed twice daily in equal amounts; samples were taken at each feeding to determine dry matter. All experimental procedures followed in this digestion and metabolism trial including collection and analysis of biological samples, calculation of energy values and statistical interpretation were similar to those described in experiment 1; sodium, potassium in soils as well as in plant samples were analysed with the help of a Perkin \& Elmer 403 Atomic Absorption Spectrophotometer, after wet ashing the samples (Sandel 1950). Chloride was analyzed according to Bradsley and Lancaster (1965).

\section{Results and Discussion}

\section{Experiment 1.}

Crude protein content of haloxylon (10\%) was markedly lower than that of alfalfa (15\%), with acacia at an intermediate level (13\%)(Table 2). Similar values have been reported previously from this area (Bhattacharya 1987) and elsewhere (ILCA 1980, NRC 1971). Both the calcium and phosphorus content of haloxylon were lower than those of the other 2 forages studied here.

The composition and digestibilities of the dietary nutrients are given in Tables 1 and 3 . Crude protein digestibility decreased $(P<.01)$ from $73 \%$ for alfalfa, to $68 \%$ for haloxylon, and to $55 \%$ for the acacia diet; the same trend was observed in the digestibilities of dietary organic matter and crude fiber, respective values being 66 and $44 \%$ for alfalfa, 56 and $33 \%$ for haloxylon, and 53 and $16 \%$ for acacia. Wilson (1977) in Australia reported digestibilities of $14 \%$ and $63 \%$ for fiber and crude protein respectively for acacia forage fed to sheep. Calculated digestibilities from the prediction equation (digestible protein $=0.897 \mathrm{cr}$. protein -3.43 ) reported by IFI (1979), however, were $76 \%$ for acacia and $66 \%$ for haloxylon forages. Daily nitrogen retention for both the alfalfa and haloxylon diets was $4 \mathrm{~g}$, or $21 \%$ of nitrogen intake (Table 4). Nitrogen balance in the group fed haloxylon, however, was negative (-1.9 $\mathbf{g}$ /day). Thus, even though the percent nitrogen absorbed out of intake was higher in haloxylon group (67\%) than in the acacia-fed group (55\%), there seemed to be no retention of the absorbed nitrogen in the former group. The digestible protein, digestible energy, and metabolizable energy values of acacia and haloxylon forages were not markedly different from each other (Table 5), the average values being $7 \%, 2 \mathrm{Mcal} / \mathrm{kg}$ and $1.6 \mathrm{Mcal} / \mathrm{kg}$, respectively. The protein quality of haloxylon forage was questionable and requires further studies. The metabolizable energy value of acacia leaves reported by Economides and Hadjidemetrion (1964) was 1.1 $\mathrm{Mcal} / \mathrm{kg}$. Thus, acacia and haloxylon forage can be compared to poor quality roughages such as cereal straw as a feed for livestock.
Table 5. Feed values of alfalia, acacia, atriplex and haloxylon fornges for Najdi sheep (on dry matter basia).

\begin{tabular}{|c|c|c|c|}
\hline Forages & $\begin{array}{l}\text { Digestible } \\
\text { protein } \\
(\%)\end{array}$ & $\begin{array}{c}\begin{array}{c}\text { Digestible } \\
\text { energy }\end{array} \\
(\mathrm{Mc}\end{array}$ & $\begin{array}{c}\text { Metabolizable } \\
\text { energy }\end{array}$ \\
\hline \multicolumn{4}{|c|}{ Experiment I } \\
\hline Alfalfa hay, sun-cured & 10.8 & 2.55 & 2.08 \\
\hline $\begin{array}{l}\text { Acacia foliage, sun-cured } \\
\text { Haloxylon clippings, }\end{array}$ & 7.3 & 1.90 & 1.55 \\
\hline sun-cured & 6.7 & 1.96 & 1.60 \\
\hline \multicolumn{4}{|c|}{ Experiment II } \\
\hline Alfalfa, green & 17.3 & 2.73 & 2.23 \\
\hline Atriplex clippings & 14.2 & 2.05 & 1.67 \\
\hline
\end{tabular}

\section{Experiment 2.}

Sodium, potassium, and chloride contents of the soil surface in the saline area of $5.52,0.18$, and $8.70 \%$, respectively, were significantly higher than the respective values of $0.74,0.03$ and $1.64 \%$ for the normal soil surface on the same range (Table 6). However, the soil-salt content of both areas was similar at the 25 and $50 \mathrm{~cm}$ depths. The atriplex clippings collected from both areas were not different in their salt contents, the average values being $10.2 \%$ sodium, $2.5 \%$ potassium, and $16.6 \%$ chloride, on a dry matter basis (Table 6). Wilson (1965) reported values of $8.2 \%$ sodium, $2.7 \%$ potassium, and $7.1 \%$ chloride in Atriplex nummularia in Australia; the leaf of Atriplex vesicaria in their study was as high as $9.6 \%$ sodium, 2.8 potassium, and $13.4 \%$ chloride. The Middle East feed data (IFI 1979), however, showed $4.41 \%$ sodium and $1.35 \%$ potassium for Atriplex halimus, on a dry matter basis. The chemical composition of the atriplex clippings analyzed (Table 1) had high crude protein (18.5\%) yet low crude fiber (23.7\%) for a forage, on a dry matter basis. Crude protein was similar to the $18.8 \%$ reported by Wilson (1966) for Atriplex nummularia. Organic matter content of atriplex was low (73\%). Organic matter digestibility of atriplex was 4.8 percentage units lower than that of alfalfa hay (Table 3). Crude fiber digestibility of atriplex was lower $(P<.01)$ than that of alfalfa ( 39 vs $54 \%$ ). Crude protein digestibility, however, was higher in atriplex (79\%) than in alfalfa (71\%). Wilson (1966) reported that Atriplex nummularia in semi-arid Australia had organic matter digestibility of $55 \%$ and crude protein digestibility of $78 \%$, which are not markedly different from the data reported here. Nitrogen utilization values in Table 4 show that not only the nitrogen absorption from atriplex was higher than that from alfalfa, but both nitrogen retention, as well as percent nitrogen retained out of that consumed or absorbed, were also higher than those of alfalfa reflecting the superior quality of atriplex crude protein. Energy and protein values of atriplex presented in Table 5 show that the shrub, even though low in energy value, its digestible protein content approaching that of a legume forage.

Table 6. Sodium, potassium and chloride contents (dry matter basis) of soll at various depths and of salt bush (A triplex hallmus) in Wadi Slrhan Range of Northern Saudi Arabia.

\begin{tabular}{|c|c|c|c|c|c|c|c|c|}
\hline \multirow[b]{3}{*}{ Minerals } & \multicolumn{4}{|c|}{ Normal soilt site } & \multicolumn{4}{|c|}{ Saline soil ${ }^{2}$ site } \\
\hline & \multicolumn{3}{|c|}{ Soil depth } & \multirow{2}{*}{$\begin{array}{l}\text { Atriplex } \\
\text { halimus }\end{array}$} & \multicolumn{3}{|c|}{ Soil depth } & \multirow{2}{*}{$\begin{array}{l}\text { Atriplex } \\
\text { halimus }\end{array}$} \\
\hline & Surface & $25 \mathrm{~cm}$ & $50 \mathrm{~cm}$ & & Surface & $24 \mathrm{~cm}$ & $50 \mathrm{~cm}$ & \\
\hline $\begin{array}{l}\text { Sodium, \% } \\
\text { Potassium, \% } \\
\text { Chloride, } \%\end{array}$ & $\begin{array}{l}0.74 \\
0.03 \\
1.64\end{array}$ & $\begin{array}{l}0.69 \\
0.06 \\
1.38\end{array}$ & $\begin{array}{l}0.68 \\
0.05 \\
1.33\end{array}$ & $\begin{array}{r}10.66 \\
2.56 \\
16.98\end{array}$ & $\begin{array}{l}5.52 \\
0.18 \\
8.70\end{array}$ & $\begin{array}{l}0.87 \\
0.06 \\
1.38\end{array}$ & $\begin{array}{l}0.75 \\
0.05 \\
1.11\end{array}$ & $\begin{array}{r}9.76 \\
2.56 \\
16.21\end{array}$ \\
\hline
\end{tabular}

iSoil surface without any salt deposit.

${ }^{2}$ Soil surface with salt deposit. 


\section{Literature Cited}

A.O.A.C. 1980. Official Methods of Analysis. Association of Official AnaIytical Chemists, Washington, D.C.

Bhattacharya, A.N. 1987. Nutrient composition and feed values of commonly browsed desert range shrubs, forbs and tree leaves in Northern Saudi Arabia. Tech. Rep. Food and Agr. Organization of the United States, Rome.

Bradeley, C.E., and J.A. Lancaster. 1965. Methods of Soil Analysis. Amer. Soc. Agron., Madison, Wis.

Crampton, E.W., L.E. Lloyd, and V.G. Mecksy. 1957. The caloric value of TDN. J. Anim. Sci. 16:541-545.

Duncan, D.B. 1955. Multiple range and Multiple F tests. Biom. 11:1-42.

Economides, S., and D. Hadjidemetrion. 1974. The nutritive value of some agricultural by-products. Agr. Res. Inst., Ministry of Agr. and Natural Resour., Cyprus. Tech. Bull. 18.

Fiake, C.H., and Y. Subbarow. 1925. The colorimetric determination of phosphorus. J. Biol. Chem. 66:375.

IF1. 1979. Arab and Middle East Tables of Feed Composition. International Feedstuffs Institute, Utah Agr. Exp. Sta., Res. Rep. 30, Logan, Utah.
ILCA. 1980. Browses in Africa: The current state of knowledge. In: H.N. Lee Houerou (ed). International Livestock Center for Africa. Addis Ababa, Ethiopia.

NRC. 1981. Nutrient requirements of goats: Angora, dairy and meat goats in temperate and tropical countries. Nat. Res. Counc., Nat. Acad. Sci., Washington, D.C.

NRC. 1971. Atlas of nutritional data of the United States and Canadian Feeds. Committee on Animal Nutrition, Nat. Res. Counc., Nat. Acad. Sci., Washington, D.C.

Sandel, E.B. 1950. Colorimetric determination of traces of metals. Interscience Pub. Inc., New York.

Steel, R.G., and J.H. Torrie. 1980. Principle and procedures of statistics. A biometrical approach. 2nd Ed. McGraw-Hill, Singapore.

Wilson, A.D. 1977. The digestibility and voluntary intake of the leaves of trees and shrubs. Australian J. Agr. Res. 28:501-508.

Wilaon, A.D. 1966. The value of Atriplex (salt bush) and Kochia (blue bush) species as food for sheep. Australian J. Agr. Res. 17:147-152.

Wilson, A.D. 1965. The intake and excretion of sodium by sheep fed on species of Atriplex (Saltbush) and Kochia (blue bush) species as food for sheep. Australian J. Agr. Res. 7:155-163. 